\title{
NEW APPROACHES TO THE IMPLEMENTATION OF THE MINING TECHNOLOGY OF DIMENSION STONE USING A CLOSE-SET DRILLING
}

The analysis of the current state the non-blasting monolith extraction technology was conducted. The further research direction was substantiated. Has been considered and justified the rational parameters of close-set drilling technology of dimension stones. Solution is offered that consist the combined drilling (a close-set and a holes line drilling), that provides to increase of stone splitting efficiency under its own weight. The calculation of the parameters of the scheme of partial underdrilling at a monolith of stone with the purpose of reducing the volume of drilling works is given. Diagrams of tensile stress changes depending on the specific area of splitting were built. A rational correlation between the drilling parameters of the holes has been established by solving the problems of loading the cantilever beam and stress concentration by the Kirsch solution. The most important parameter for the implementation of this technology is the ratio of monoloth hight to its length. Engineering formulas are proposed for calculating the technological parameters of the realization of the "gravitational-hole" stone splitting. The configuration of a rough block of stones is determined under which this technology can be realized. Creating of close-set holes provides the increase of maximal tensile stress with equal values of specific splitting area ratio. It is established that the effective drilling depth of close-set holes is 43,2 \% of monolith height. It is estimated that combined drilling method application of savings from drilling operation will be 11,36\%.

Keywords: dimension stone; non-explosive of mining processes; drilling of boreholes; brittle fracture.

Introduction and problem statement. The technology of mining dimension stone intended to perform separation of regular geometric shape of stone parts while preserving its properties of strength and integrity. These criteria corresponds to a number of nonexplosive mining technologies where the basic principle of material failure is to create separation cracks due to the abrasive cutting and drilling. The Abrasive cutting is performed by diamond wire saws and their use may be limited by the presence of a well-developed rock jointing, with a high probability of clamping diamond rope. Another technology is a technology close-set stone drilling aimed at creation of cracks by drilling a line of holes. The quality properties of stone extracted in this way can be compared only with the diamond wire cutting technology. With maximum preservation of the stone, this technology is not without drawbacks, such as the loss of stone during the gaping formation, the width of which is equal to the diameter of the hole. In addition, the close-set drilling technology is characterized by large volumes of drilling, which is quite costly. This technology is the only possible in difficult geological conditions and mining of large-sized monoliths. It is possible to overcome its main drawback ( the large volume of drilling operations) through the development of technology for splitting of the monolith under its own weight with a partial close-set drilling. It requires a detailed study and an analysis of rock splitting power parameters and the connection to geometric parameters of mining processes.

Analysis of researches and publications. The technology of close-set drilling is the simplest of all splitting technologies as the main research of it was to evaluate the volume of stone losses. This issue is dedicated to the works of such scholars as O. O. Kisel , V.V. Kotenko, and V.V. Korobiychuk [1-5]. The Basic research is the geometric patterns calculations of the stone loss during the close-set drilling of monoliths and solution are reduced to the study options that would ensure minimal production losses. Another weak point of this technology is the accuracy of the drilling operation of a continuous line of the holes depending on volume of stone losses. This issue was thoroughly studied by R. V. Sobolewskiy, and A. V. Shlapak [6]. Major decisions and recommendations for this technology are to determine the limits of deviation from the vertical axis of the holes without significant loss of stone volume. In scientific literature the questions of physics processes in the large monoliths extraction were considered by such scientists as M. T. Bakka, S. A. Zhukov, K. K. Tkachuk. They investigated the power settings ensuring splitting of large size stone monoliths [7-9, 12-20]. The splitting methods considered in their works did not provide such preservation and quality, as a method of close-set holes drilling. It is first time, when the possibility of splitting stone using the forces caused by the stone own weight was considered $[10,11]$. In theory it was proved that the possibility of splitting during previous horizontal drilling of holes line, that should ensure the monolith position in the array as a cantilevered beam and further splitting in the plane creating the largest tensile stress. However, in the application to real parameters of monoliths separation this possibility has not been studied in detail. This technology requires a detailed study and analysis to establish rational boundaries of drilling technological parameters and maximum savings. 
The aim of the articles is to determine technological parameters of line holes drilling during the of the monolith stone separating process using gravity-hole splitting.

Basic material report of the article.

The technology of the close-set monolith drilling is realized by drilling hole line of increased diameter with a certain level of overlap that except the formation of an abutment between them. Reducing the cost of this technology can be achieved by drilling holes in a solid line on a certain depth and drilling in holes on the entire height of the specified interval (Fig. 1).

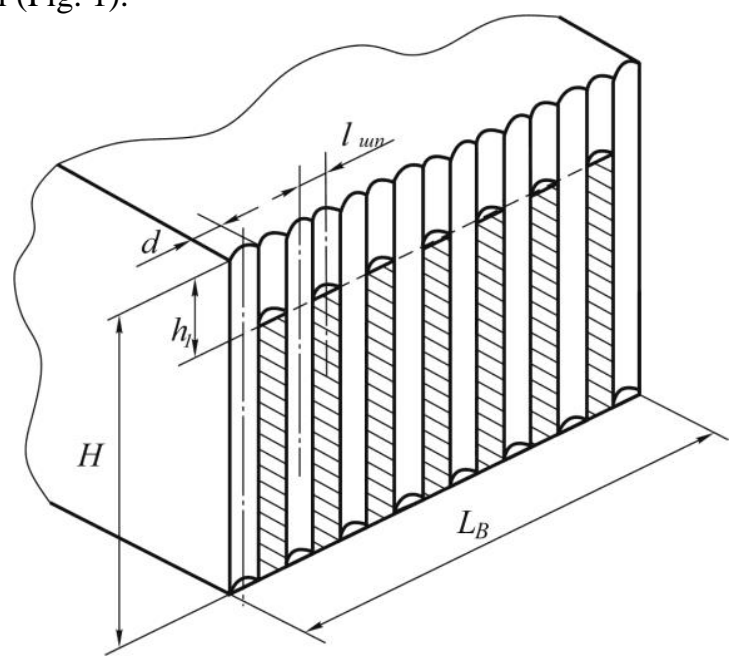

Fig. 1. Drilling scheme in the implementation of stone splitting by the gravitational method

With this method of extraction the splitting in the abutment between the holes will be provided by the effort made by the monolith's own weight. With the implementation of this technology the basic calculation will be to establish the value of the area to begin the activation of splitting rocks of specified weight depending on the geometrical parameters of the monolith. In general the formula determining this dependence is described by equations to determine the stress of a cantilever beam taking into account stress concentration on the walls of holes while finding the solution to the Kirsch's problem [10,11]:

$$
\sigma_{\min }=\frac{9 \rho \mathrm{gl}^{2}}{K_{S} \cdot b \cdot h^{2}}
$$

where $\rho$ - the density rocks of the monolith, $\mathrm{t} / \mathrm{m}^{3} ; 1$ - the length of the monolith (distance from the splitting line to the free surface of open-pit bench), $\mathrm{m}$; Ks - ratio of the specific splitting plane (the ratio of the area of line holes to the total area of the monolith splitting); $b$ - width of the monolith, $\mathrm{m} ; \mathrm{h}$ - the height of the monolith, $\mathrm{m}$.

As practice shows extraction of crystalline rocks, the average value of the limit of tensile strength at which the gradual stone destruction waries from $8 \mathrm{MPa}$ to $12 \div 15 \mathrm{MPa}$ (passports strength). In the calculations of the entire height of the monolith drilling according to formula 1 and the given parameter, the process of steady stone splitting begins when the ratio of the splitting specific plane is about 4,5\%. In this case, it is necessary to split almost the entire area and to perform drilling operations in the amount of 95,5\% from the amount of work in the close-set drilling. Implementing this, the technology of gravity-hole stone splitting is quite inefficient and a slight decrease in drilling volume is observed only in comparison with the line of drilling holes. The drilling volumes may be decreased slightly by running the process of close-set drilling holes only at the top of the monolith.

The formula 1 shows that increasing the ratio of monolith length 1 to height $\mathrm{h}$ separating area will increase the volume of splitting forces, and consequently to reduce the required volume of drilling operations. From the technological point of view there is no possibility to change the ratio of the length of the monolith to its height, so the only way this value varies due to the close-set drilling of the top layer of the marked splitting area (Fig. 2). In addition, the weight of the layer located above the line of maximum tensile with the magnitude of this layer $\mathrm{h}_{1}$ causes the increase of the stress. 


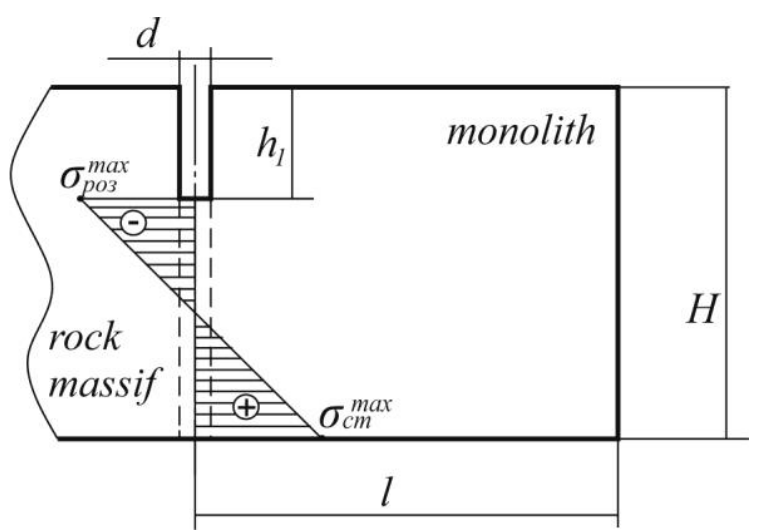

Fig. 2. The diagram of the forces in the stone splitting by the gravitational method

Taking into account the close-set drilling of the monolith upper layer and the weakening the splitting area of the lower layer by drilling line of holes with some interval the formula for calculating the maximum tensile stress will be as follows (2):

$$
\sigma \max =\frac{9 \rho g\left(1+\frac{h_{1}}{H}\right) l^{2}}{K_{S} \cdot b \cdot\left(H-h_{1}\right)^{2}}
$$

The calculation was performed for the parameters of the monolith length $1=6 \mathrm{~m}$; height of the monolith $\mathrm{h}=5$ $\mathrm{m}$ and density of the rock mass $2,85 \mathrm{t} / \mathrm{m}^{3}$. The range of the ratio value of the specific splitting plane is $0,011 \div 1,0$. The diagrams of maximum stresses changes were built according to the analytical expression of the formula 2 and the initial conditions expressed by the ratio of the specific plane of splitting (Fig. 3). It is necessary to consider also that the maximum ratio value of the specific splitting planes corresponds to the ratio of drilling-hole diameter to the distance between holes $\mathrm{Ks}=\mathrm{d}_{\text {шा }} / 1_{\text {шп }}$, with known diameter value of $40 \mathrm{~mm}$ and the allowed distance between holes of $200 \mathrm{~mm}$, providing high-quality of stone splitting, the maximum value of Ks will be 0,2.

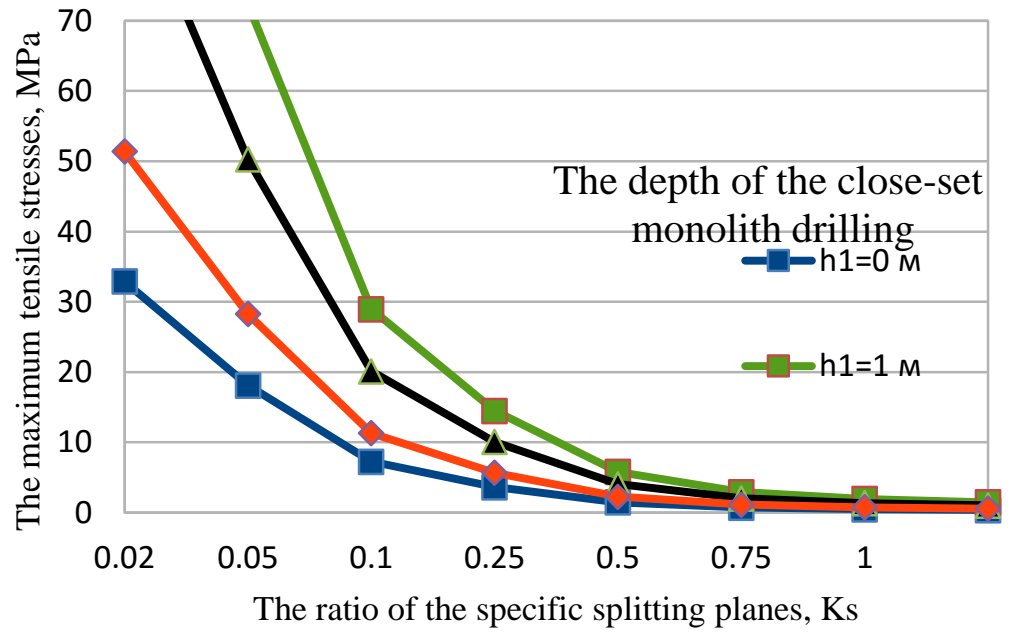

Fig. 3. Diagrams of tensile stress changes depending on the specific area of splitting

The diagrams in figure 3 shows the creation of a pre-drilled line of holes providing an increase in the maximum tension stress with equal ratio values of the specific splitting planes. Thus the close-set drilling makes the desired effect and at the maximum value of $\mathrm{Ks}=0,2$ the depth of drilling the line of holes will be $2,16 \mathrm{~m}$ or $43,2 \%$ of the monolith height. The drilling volume of this splitting plane are defined as the amount of the closeset drilled plane and the amount of exposure areas formed by line of holes, that is $88,64 \%$ of the total splitting area. In this case the amount of savings from drilling in comparison with the technology of a close-set drilling are $11,36 \%$, that is 2,5 times better economy indicator of drilling than in the previous case.

Conclusions. According to the analytical investigations and calculations, the efficiency of the technologies of gravity-hole stone extraction was established using the proposed drilling scheme and calculation formula. The maximum value of the effective depth of close-set drilling holes line is $43,2 \%$ of the total drilling depth. The maximum amount of savings from drilling applying this method will be $11,36 \%$. This technology is effective in extracting of large size blocks of stone, where the main condition is the preservation of its integrity. 
Список використаної літератури:

1. Котенко В.В. Дослідження втрат блочної сировини при різних технологічних способах відокремлення блоків / В.В. Котенко, О.О. Кісєль // Вісник Житомирського державного технологічного університету. 2007. - № 40. - C. 177-185.

2. Кісєль O.O. Вивчення закономірностей утворення і формування втрат при видобуванні декоративного облицювального каменю методом суцільного буріння / О.О. Кісєль, Р.В. Соболевський // Вісник Житомирського державного технологічного університету. - 2006. - № 38. - С. 183-188.

3. Кісєль О.О. Дослідження шляхів мінімізації втрат при буровибуховому способі видобування блоків декоративного каменя / О.О. Кісєль, Р.В. Соболевський, В.В. Коробійчук // Вісник Житомирського державного технологічного університету. - 2006. - № 39. - С. 301-308.

4. Котенко B.B. Порівняльний аналіз втрат каменю та продуктивності робіт при підготовці монолітів великого об'єму до виймання різними технологічними комплексами / B.B. Котенко, В.Г. Левицький // Тези наукових доповідей XXX наукової конференції присвяченій 45-ій річниці Житомирського державного технологічного університету. - Житомир. - 2005. - С. 72-74.

5. Коробійчук В.В. Вплив бурових робіт на якість первинного моноліту при його відокремленні від масиву / B.B. Коробійчук, B.В. Котенко // Вісник ЖІТІ. Серія : Технічні науки. - 2008. - № 4. - С. 160-166.

6. Sobolevskyi R. Quality control of drilling operations for efficiency upgrading of creation of separation plane by lineage drilling / R.Sobolevskyi, V.Shlapak // Metallurgicaland mining industry. -2016. - № 2. - Pp. 167-173.

7. Бакка M.T. Структури технологій відокремлення монолітів декоративного каменю від масиву 3 використанням невибухових руйнуючих засобів (НР3) / М.Т. Бакка, С.В. Яворська // Вісник ЖДТУ. 2003. - № 1. - С. 118-126.

8. Жуков С.A. Теоретические основы динамики процесса откола камня шпуровыми методами в карьере / C.A. Жуков, С.В. Кальчук // Сборник научных трудов «Добыча, обработка и применение природного камня». - 2015. - № 15. - С. 100-104.

9. Жуков С.О. Аналітична модель процесу пасирування блоків каменю шпуровими методами в субдинамічному режимі навантаження / C.O. Жуков, С.В. Кальчук // Гірничий Вісник: Науково-технічний збірник ДВНЗ «Криворізький національний технічний університет». - 2015. - № 100. - С. 75-79.

10. Жуков С.О. Обгрунтування параметрів бурових робіт при видобуванні блочного облицювального каменю статичними методами / С.О. Жуков, С.В. Кальчук, В.О. Шлапак // Гірничий Вісник: Науково-технічний збірник ДВНЗ «Криворізький національний технічний університет». - 2016. - № 101. - С. 84-88.

11. Kalchuk $S$. Ways of reducing loss of ornamental stone using the combined technology of nonexplosive mining method / S.Kalchuk // Scientific Reports on Resource Issues. Efficiency and Sustainability in the Mineral Industry. - 2013. - C. 130-134.

12. Ткачук K.K. Методика досліджень полів напружень навколо шпура при статико-динамічному методі видобування кам'яних блоків / К.К. Ткачук, Т.В. Гребенюк, С.В. Диняк // Вісник НТУУ «КПІ». Серія «Гірництво» : Зб-к наук. праць. - 2014. - № 24. - С. 42-49.

13. Криворучко А.О. Застосування інформаційно-коп'ютерних технологій для дослідження гірничо-екологічних особливостей родовищ рудних i нерудних корисних копалин / A.O. Криворучко, В.В. Коробійчук, Ю.О. Подчашинський, О.О. Ремезова // Вісник Житомирського державного технологічного університету /Серія: Технічні науки. - 2007. - №. 1 (40). - С. 186-195.

14. Коробійчук В.В. Дослідження впливу розмірів первинного моноліту природного каменю на питомі втрати природного каменю / B.B. Коробійчук // Вісник Національного університету водного господарства та природокористування / Технічні науки. - 2012. - № 1 (57). - С. 150-154.

15. Коробійчук В.В. Паспортизація кінцевої товарної продукції блочного кар'єру / В.В. Коробійчук, О.А. Зубченко // Вісник Житомирського державного технологічного університету / Серія : Технічні науки. - Житомир, 2008. № 3 (46). - С. 142-147.

16. Коробійчук В.В. Дослідження зміни кутової швидкості падіння моноліту залежно від його геометричних розмірів та положення в просторі / В.В. Коробійчук // Вісник Житомирського державного технологічного університету / Технічні науки. - 2012.-№ 2 (61). - С. 171-174.

17. Коробійчук В.B. Удосконалення системи поточного планування видобування блоків природного каменю / B.В. Коробійчук // Вісник Житомирського державного технологічного університету / Технічні науки. - 2012.T. 1, № 3 (62). - C. 122-125.

18. Криворучко А.О. Розробка узагальненої методики геометризації масивів природного каменю 3 метою отримання комплексної моделі родовища / А.О. Криворучко, В.В. Коробійчук, С.С. Іськов // Вісник Житомирського державного технологічного університету / Технічні науки. - 2012. - № 4 (63). - С. 190-202.

19. Коробійчук B.B. Дослідження впливу висоти та ширини моноліту, який перекидається, на його руйнування / B.В. Коробійчук // Вісник Житомирського державного технологічного університету / Технічні науки. - 2013. № 1 (64). - С. 134-138.

20. Коробийчук B.B. Определение рационального способа извлечения монолитов камня при проведении капитальных траншей/ B.B. Коробийчук, C.C. Иськов // Технологический аудит и резервы производства. 2013. - T. 5. - №. 1 (13). - C. 12-16.

\section{References:}

1. Kotenko, V.V. and Kisel, O.O. (2007), «Doslidzhennja vtrat blochnoi' syrovyny pry riznyh tehnologichnyh sposobah vidokremlennja blokiv» [Investigation of dimension stone raw material losses with different methods of block extraction], Bulletin ZSTU, Engineering, No. 40, pp. 177-185.

2. Kisel, O.O. and Sobolevskyi, R.V. (2006), «Vyvchennja zakonomirnostej utvorennja i formuvannja vtrat pry vydobuvanni dekoratyvnogo oblycjuval'nogo kamenju metodom sucil'nogo burinnja» [Study appropriations of creating and forming of losses by the decorative stone recovering by the method of the continuous boring drilling], Bulletin ZSTU, Engineering, No. 38, pp. 183-188. 
3. Kisel, O.O., Sobolevskyi, R.V. and Korobijchuk, V.V. (2006), «Doslidzhennja shljahiv minimizacii' vtrat pry buro vybuhovomu sposobi vydobuvannja blokiv dekoratyvnogo kamenja» [Investigation of minimize lose ways by the blasting methods of dimension stone extractions], Bulletin ZSTU, Engineering, No. 39, pp. 301-308.

4. Kotenko, V.V. and Levyckyi, V.G. (2005), «Porivnjal'nyj analiz vtrat kamenju ta produktyvnosti robit pry pidgotovci monolitiv velykogo ob'jemu do vyjmannja riznymy tehnologichnymy kompleksamy» [Comparative analysis of stone losses and work productivity in preparing to extraction of large-size monoliths by the various technological complexes], Tezy naukovyh dopovidej XXX naukovoi' konferencii' prysvjachenij 45-ij richnyci Zhytomyrs'kogo derzhavnogo tehnologichnogo universytetu, Zhytomyr, Ukraine, pp. 72-74.

5. Korobijchuk, V.V. and Kotenko, V.V. (2008), «Vplyv burovyh robit na jakist' pervynnogo monolitu pry jogo vidokremlenni vid masyvu» [Some questions on conducting of boring works at boring drilling of primary monolith], Bulletin ZSTU, Engineering, No. 47, pp. 160-166.

6. Sobolevskyi, R. and Shlapak, V. (2016), «Quality control of drilling operations for efficiency upgrading of creation of separation plane by lineage drilling», Metallurgicaland mining industry, No 2, pp. 167-173.

7. Bakka, M.T. and Javorska, S.V. (2003), «Struktury tehnologij vidokremlennja monolitiv dekoratyvnogo kamenju vid masyvu z vykorystannjam nevybuhovyh rujnujuchyh zasobiv (NRZ)» [Structures of extraction from an array ornamental stone monolith technologies by the nonexplosive destruction facilities (NDF)], Bulletin ZSTU, Engineering, No. 24, pp. 118-126.

8. Zhukov, S.A. and Kalchuk, S.V. (2015), «Teoreticheskie osnovy dinamiki protsessa otkola kamnya shpurovymi metodami v kar'ere» [Theoretical bases of dynamical hole splitting processes in a quarry], Collection of scholarly works «Recovery, processing and application of natural stone», Vol. 15. pp. 100-104.

9. Zhukov, S.A. and Kalchuk, S.V. (2015), «Analitychna model' procesu pasyruvannja blokiv kamenju shpurovymy metodamy v subdynamichnomu rezhymi navantazhennja» [The analytical model of process of пасирування blocks of stone by шпуровыми methods in the subdynamic mode of loading], Mining journal of Kryvyi Rih National University, Vol. 100, pp. 75-79.

10. Zhukov, S.A., Kalchuk, S.V. and Shlapak, V.O. (2016), «Obg'runtuvannja parametriv burovyh robit pry vydobuvanni blochnogo oblycjuval'nogo kamenju statychnymy metodamy» [Substantiation of parameters of drilling operations during the extraction of dimension facing stone of static methods], Mining journal of Kryvyi Rih National University, Vol. 101, pp. 84-88.

11. Kalchuk, S. (2013), «Ways of reducing loss of ornamental stone using the combined technology of nonexplosive mining method», Scientific Reports on Resource Issues. Efficiency and Sustainability in the Mineral Industry, Vol. 1, pp. 130-134.

12. Tkachuk, K.K., Grebenjuk, T.V. and Dynjak, S.V. (2014), «Metodyka doslidzhen' poliv napruzhen' navkolo shpura pry statyko-dynamichnomu metodi vydobuvannja kam'janyh blokiv» [Blast-hole tension fields research under static-dynamic method of the block stone extraction], Herald of the National Technical University of Ukraine "Kiev Polytechnic Institute", Series of Mining, Vol. 24, pp. 42-49.

13. Kryvoruchko, A.O., Korobiichuk, V.V., Podchashyns'kyj, Ju.O. and Remezova, O.O. (2007), "Zastosuvannja informacijnokop'juternyh tehnologij dlja doslidzhennja girnycho-ekologichnyh osoblyvostej rodovyshh rudnyh i nerudnyh korysnyh kopalyn", Visnyk Zhytomyrs'kogo derzhavnogo tehnologichnogo universytetu. Serija: Tehnichni nauky, Vol. 1 (40), pp. 186-195.

14. Korobiichuk, V.V., Sobolevs'kyj, R.V., Podchashyns'kyj, Ju.O., Zubchenko, O.A. and Remezova, O.O. (2007), "Doslidzhennja vplyvu burovybuhovyh robit na jakist' blochnoi' produkcii' kar'jeru na osnovi vyznachennja geometrychnyh harakterystyk i'i' trishhynuvatosti', Visnyk Zhytomyrs'kogo derzhavnogo tehnologichnogo universytetu. Serija: Tehnichni nauky, Vol. 3 (42). pp. 143-150.

15. Korobiichuk, V.V. and Zubchenko, O.A. (2008), «Pasportyzacija kincevoi' tovarnoi' produkcii' blochnogo kar'jeru», Visnyk Zhytomyrs'kogo derzhavnogo tehnologichnogo universytetu, Serija Tehnichni nauky, No. 3 (46), Zhytomyr, pp. 142-147.

16. Korobiichuk, V.V. (2012), «Doslidzhennja zminy kutovoi' shvydkosti padinnja monolitu zalezhno vid jogo geometrychnyh rozmiriv ta polozhennja $\mathrm{v}$ prostori», Visnyk Zhytomyrs'kogo derzhavnogo tehnologichnogo universytetu, Serija Tehnichni nauky, No. 2 (61), Zhytomyr, pp. 171-174.

17. Korobiichuk, V.V. (2012), «Udoskonalennja systemy potochnogo planuvannja vydobuvannja blokiv pryrodnogo kamenju», Visnyk Zhytomyrs'kogo derzhavnogo tehnologichnogo universytetu, Serija Tehnichni nauky, Vol. 1, No. 3 (62), Zhytomyr, pp. 122-125.

18. Kryvoruchko, A.O., Korobiichuk, V.V. and Is'kov, S.S. (2012), «Rozrobka uzagal'nenoi' metodyky geometryzacii' masyviv pryrodnogo kamenju z metoju otrymannja kompleksnoi' modeli rodovyshha», Visnyk Zhytomyrs'kogo derzhavnogo tehnologichnogo universytetu, Serija Tehnichni nauky, No. 4 (63), Zhytomyr, pp. 190-202.

19. Korobiichuk, V.V. (2013), «Doslidzhennja vplyvu vysoty ta shyryny monolitu, jakyj perekydajet'sja, na jogo rujnuvannja», Visnyk Zhytomyrs'kogo derzhavnogo tehnologichnogo universytetu, Serija Tehnichni nauky, No. 1 (64), Zhytomyr, pp. 134-138.

20. Korobiichuk,V.V. and Is'kov, S.S. (2013), «Opredelenie racional'nogo sposoba izvlechenija monolitov kamnja pri provedenii kapital'nyh transhej», Tehnologicheskij audit i rezervy proizvodstva, Vol. 5, No. 1 (13), Zhytomyr, pp. 12-16.

КАЛЬЧУК Сергій Володимирович - кандидат технічних наук, доцент кафедри розробки родовищ корисних копалин ім. проф. Бакка М.Т. Житомирського державного технологічного університету.

Наукові інтереси:

- гірництво

- відкрита розробка родовищ;

- моделювання процесів гірничого виробництва. 